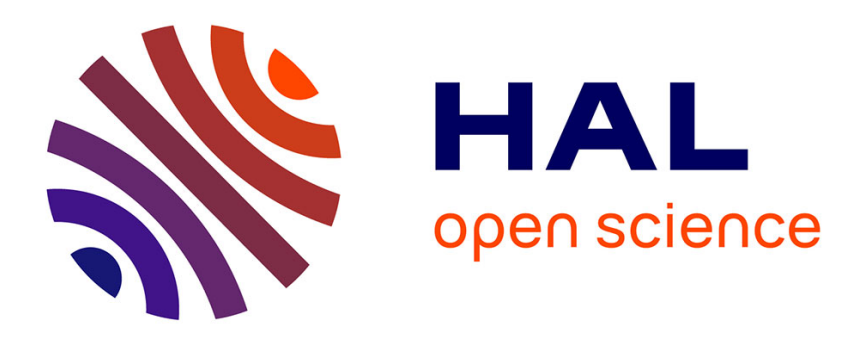

\title{
School divisions and inequalities in funding, access to schools and staffing \\ Patrice Caro
}

\section{To cite this version:}

Patrice Caro. School divisions and inequalities in funding, access to schools and staffing. Pierre

Champollion. Territorialization of education. Trend or necessity, ISTE, 2020. halshs-02780825

\section{HAL Id: halshs-02780825 \\ https://shs.hal.science/halshs-02780825}

Submitted on 4 Jun 2020

HAL is a multi-disciplinary open access archive for the deposit and dissemination of scientific research documents, whether they are published or not. The documents may come from teaching and research institutions in France or abroad, or from public or private research centers.
L'archive ouverte pluridisciplinaire HAL, est destinée au dépôt et à la diffusion de documents scientifiques de niveau recherche, publiés ou non, émanant des établissements d'enseignement et de recherche français ou étrangers, des laboratoires publics ou privés. 


\section{School divisions and inequalities in funding, access to schools and staffing}

\subsection{Summary}

The French education system produces its own inequalities, in addition to those generated by the demographic, economic, cultural and social context in which it operates. How many different versions of France appear when we analyze the inequalities in the distribution of both financial and human resources by the different levels of the State and by the various local authorities, as well as the inequalities in physical accessibility (roads, for example) to high schools? Can we talk about divisions concerning the disparities observed between regional education authorities, departments, cantons and communes in this area? After examining the inequalities in the financial allocation by local authorities to middle and high schools, the inequalities in road access to these establishments and the disparities in the location of human resources (teachers, etc.) in these establishments, the use of the notion "school divide" does not really seem excessive in view of the differences observed between cantons, departments and regional education authorities....

\subsection{Introduction}

Socio-spatial inequalities are defined as "disparities experienced as injustices" (Brunet 1992). They can cover such a wide range of unequal situations that the use of the notion of division is possible. These inequalities or divisions break up the French space into several types of areas (Le Bras 2013), with radically heterogeneous living

Chapter written by Patrice CARO. 
conditions and demo-socio-economic characteristics (opposition between French overseas territory and Metropolitan France for example). The scope of initial training and schooling does not escape such divisions, as shown by the "Géographie de l'école" published regularly by the French Ministry of National Education (MEN 2017) and reports published at the end of 2018 by the Conseil national d'évaluation du système scolaire (French national council for the evaluation of the school system) or Cnesco (Schneider et al. 2018). An atlas of school divisions was presented in 2010 based on these scores from metropolitan France and overseas French territories (Caro and Rouault). An update of this atlas ${ }^{1}$ has been available online for a few months, with the authors reaffirming that:

"Academic divisions are the result of processes that lead to a breakdown in the equality of position or educational pathways between students. They can result from spatial or social processes, or their interactions, they manifest themselves for students through delay, academic difficulty, failure, drop-out."

If we select certain dimensions of the functioning of the school system, what divisions appear when we spatialize recent statistical data in a multiscalar logic? After examining disparities in funding by local authorities, it will be necessary to focus on inequalities in access to schools, then on those relating to teacher profiles according to communes and regional education authorities to confirm the existence of school divisions or to qualify this statement.

\subsection{Disparities in funding from communities}

Departments and regions are a source of educational inequality through their investments in school transport, construction and renovation of schools. Departments that contain a metropolis benefit from its public transport network. Those which are more rural must spend more on this area, especially in mountain areas. In 2015, departmental operating expenses per school child were highest in Morbihan, Cantal and Charente. The departmental councils in charge of middle schools spent on average $5.4 \%$ of their operating expenditure budgets on education, while social action absorbed 63\% (Simon and Delsol 2015). The situation was different with regard to capital expenditure on education, with an average of $15.2 \%$ of budgets devoted to this item.

57 million was the figure spent on transport in 2015 in Oise and Pas-de-Calais, compared with less than 1 million in Gers, Hauts-de-Seine, Haute-Vienne and Seine-

1. https://fracturesscolaires.fr/ (accessed June 2019). 
Saint-Denis (see Figure 1.1). It was only 6.6 million in Lozère, 13.2 million in Aveyron and 15 million in Nièvre. This is a long way from the very high spending rate seen in Seine-Maritime. On a per capita basis, these expenses distinguish mountain departments such as Jura $(96 € / \mathrm{pc}$, for an average of $30 € / \mathrm{pc})$, Corse-du-Sud $(90 € / \mathrm{pc})$, Lozère $\left(81 € / \mathrm{pc}^{2}\right)$ or Ardèche $(76 € / \mathrm{pc})$. Guyana and Mayotte are part of this group. On the other hand, the expenditure per capita ratio is lowest in departments with a metropolitan area with numerous public transport networks (Val-d'Oise: $3 € / \mathrm{pc}$; Rhône: $4 € / p c$; Var: $8 € / p c$; Val-de-Marne: $10 € / p c$; Bouches-du-Rhône: $10 € / p c$; Nord: $14 € / \mathrm{pc})$.

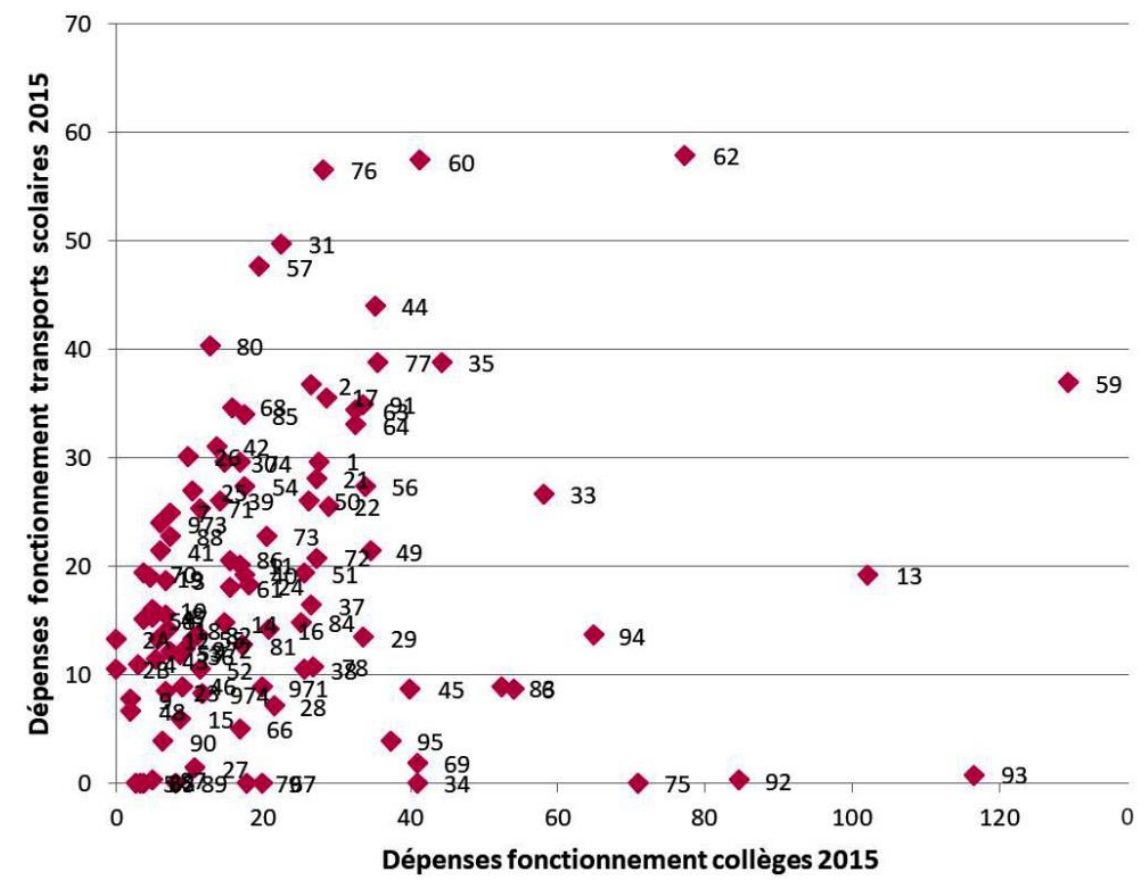

Figure 1.1. Total expenditure of departmental councils in 2015 for middle schools by department (in millions of euros) (source: DGCL 2015)

COMMENT ON FIGURE 1.1 - The Seine-Saint-Denis department (93) had operating expenditure for middle schools (116 million euros) but low operating expenditure school transport (0.8 million euros) in 2015.

2. per capita 
Logically, this variation in expenditure in millions of euros reflects the heterogeneity of the departments' demographic sizes. The Bouches-du-Rhône (1.98 million inhabitants in 2012) and the Nord (2.58 million inhabitants) are about 20 to 30 times more populated than the Hautes-Alpes $(139,000)$ or Lozère $(76,000)$. The gap is widening in terms of total operating expenditure (from 1 to 50), since the latter represents more than 100 million euros in Bouches-du-Rhône (129 million in the Nord, 116 million in Seine-Saint-Denis), just over 2 million in Lozère and Ariège and less than 3 million in the Hautes-Alpes. The number of euros spent per pupil is a more relevant indicator (approximately 800 euros per median pupil in 2015, in the case of the departments of Mayenne or Haute-Loire). It varies from 214 euros on Réunion Island to 1,947 euros in Morbihan, or 9 times more (less than 300 euros in French Guiana, and less than 400 euros in Ariège). The gap between the situation in the Nord (1,364 euros) and that of Lozère (884 euros) is narrowing in relation to the number of inhabitants ${ }^{3}$.

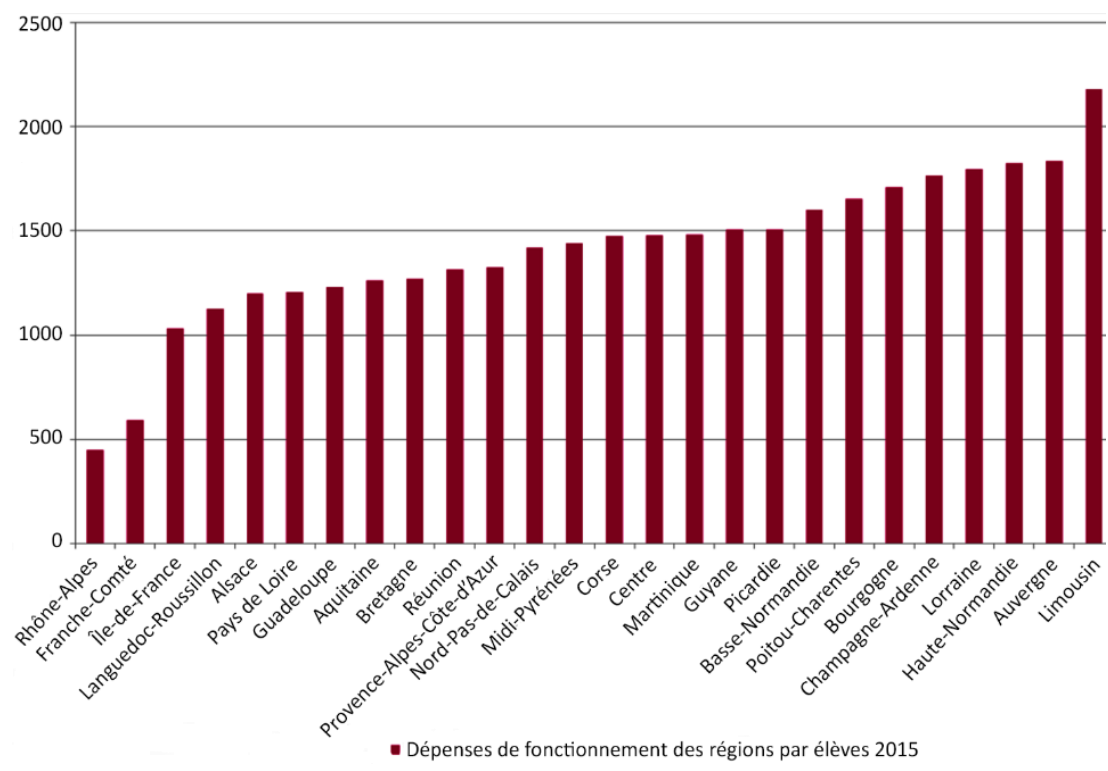

Figure 1.2. Total expenditure of the regional councils in 2015 for public and private high schools per student and per region (in euros per student) (source: DGCL 2015)

With the total expenditure of the regional councils in 2015 for public and private high schools, the scale is changing. Metropolitan regions are isolated with more than 4 million inhabitants such as Île-de-France (880 million), Nord-Pas-de-Calais (almost

3. Source: Insee. 
400 million), PACA (377 million) or Rhône-Alpes (309 million), from small rural regions with less than 1.5 million inhabitants such as Auvergne (1.32 million), BasseNormandie (1.37 million), Corsica (0.32 million) or Limousin ( 0.78 million).

Expressed in euros per high school student, the highest operating expenditure is found in Limousin, Auvergne, Normandy, Corsica, Champagne-Ardenne, Burgundy and Picardy (see Figure 1.2). All these regions without metropolitan areas (no urban areas with at least 700,000 inhabitants) spend more than the average. The presence of one or more metropolitan areas (PACAs) explains lower expenses since a large number of high school students benefit from the metropolitan public transport networks.

Expressed in euros per capita, these expenses highlight the overseas regions with ratios from 124 euros (Réunion Island) to 144 euros (French Guiana), for an average of 81 euros. This financial effort is linked to the demographic growth at work in these territories, which is stronger than in metropolitan France. The average annual rate of population change between 2007 and 2012 was $+2.4 \%$ in French Guiana and $+1 \%$ for Réunion Island, compared to $+0.5 \%$ in metropolitan France ${ }^{4}$.

Whether it is for departmental (middle schools) or regional (high schools) expenditure, French Guiana has the highest per capita expenditure ratios, with Guadeloupe. On the other hand, regions such as Franche-Comté and all its departments, except Haute-Saône, have low ratios, below average. This is partly due to the age structure of the population. The youthfulness of the population of some overseas departments contrasts with the aging population of rural regions without metropolitan areas such as Burgundy or Franche-Comte (34\% of 0-14 year-olds in French Guiana in 2013, 24\% on Réunion Island and 18\% in Jura or Martinique).

Apart from this effect of the age structure, departmental expenditure is a source of educational inequality since funding for the construction of schools, their renovation, equipment and school transport varies from 1 to 4 euros for middle schools (per capita), the key period for enrolment and from 1 to 2.6 euros for high schools. This range varies from 1 to 4 euros for operating expenses for high schools (per high school student). These differences reflect political and budgetary choices made by the local authorities in charge of schools. The current expenditure on education per local authority does not prejudge the financial efforts made by these public actors in the previous period (before 2015) or those that will be committed for the coming years.

The analysis of the cumulative investment expenditure of regions and departments from 2004 to 2014 reveals differences between departments that were greater than between regions ( 5 for 3.5 - see Figures 1.1 and 1.2). The departments and regions of

4. https://www.insee.fr/fr/statistiques/zones/1405599. 
the far northwest, but also those of Burgundy and Lorraine, stand out for investment expenditure below or around the average (less than 5,200 euros/middle school student in Ille-et-Vilaine, less than 11,600 euros/high school student in Brittany). On the other hand, some rural departments such as Haute-Marne or Landes, but also much more urban departments such as Nord, Hauts-de-Seine or Isère, spend more than the average for their middle school students (more than 10,000 euros/school in Bouchesdu-Rhône and more than 15,000 euros/high school student in Guyana or MidiPyrénées).

At a more local level, the role of communities of communes (EPCI) and communes in terms of PEDTs, PELs, PESLs, PREs ${ }^{5}$ and the implementation of extracurricular activity times (TAPs) is also a source of inequality (David 2008). According to the Ministry of National Education, during extracurricular activity times (TAPs), "students will be able to access sports, cultural and artistic activities that could develop their intellectual curiosity and enhance the pleasure of learning and being at school" (MEN 2013) ${ }^{6}$. PELs and PREs have the same objectives, namely to compensate for the lack of access to sports, cultural or artistic activities for some pupils from disadvantaged social backgrounds. It is not possible to map France, including overseas France, in terms of the municipalities and communities of municipalities currently involved in these student support schemes.

However, it can be argued that a complete reorganization of the systems, developed by some municipalities and communities of municipalities since 2013 (implementation of the new school rhythms, Decree No. 2013-77 of 24 January 2013), is under way with the current movement to merge communities of municipalities tending to become increasingly expanded and populated. In addition, the recent relaxation of the decree has had an impact.

This first approach to inequalities in funding and endowment by department and regional education authority shows that there are gaps between rural and urban areas in metropolitan France, and between overseas areas and those in metropolitan France. While their effects on school careers can be discussed (direct or indirect effects), the effects of inequalities in access time to schools are probably clearer and less debatable.

5. PEDT: projet éducatif territorial, territorial educational project; PEL: projet éducatif local, local educational project; PESL: projet éducatif social local, local social educational project; PRE: programme de réussite éducative, educational success program.

6. La réforme des rythmes scolaires à l'école primaire, press kit. Available at: http://www.education.gouv.fr/. 
Spending more time on school transport is probably a disadvantage for some isolated rural high school students. Living more than an hour from the nearest vocational school can affect individual and family choices in terms of orientation.

\subsection{Inequalities in access to schools}

Not all pupils have a middle or high school in their commune, canton or community. A very large number therefore commute, stay close to the school for week periods at a time, between boarding school and the parents' commune of residence. Some geographers refer to spatial capital as the accumulation by certain individuals, or even families, of knowledge and know-how about mobility (Ripoll and Veschambre 2005).

The following maps show the distances between municipalities that are not equipped and schools without taking into account the time distances to be covered by road to access the service. In rural areas without mountainous constraints, these mapped distances are a fairly accurate reflection of road travel times, while in mountain environments, the situation is different.

The purpose of the following maps is to provide a first look at the relative distance of the population from schools in France (metropolitan France, Mayotte, Guadeloupe, Martinique, Réunion Island, French Guiana).

The distances used in this section are calculated according to the actual geographical coordinates of the middle schools and high schools.

The principle used is that of calculating the Euclidean distance (straight distance between two points, or "as the crow flies" distance) between a place and the nearest identified school. Thus, for each spatial unit, we have a calculated distance that is then represented according to 5 classes in a range of colors of increasing intensity: from 0 to $5 \mathrm{~km}$; from 5 to $10 \mathrm{~km}$; from 10 to $15 \mathrm{~km}$; from 15 to $20 \mathrm{~km}$; more than $20 \mathrm{~km}$. Distances are calculated for three types of schools: middle schools, high schools and vocational schools, whose location is obtained through their geographic ${ }^{7}$ coordinates.

7. Source: ministère de l'Éducation nationale, de l'Enseignement supérieur et de la Recherche, May 2016. 
The reference spatial unit is chosen according to the scale of analysis. For metropolitan France, the choice was made for the municipality, thus providing sufficient precision to assess the fine variations in distance observed over the territory. These maps therefore represent the distance from each municipality to the nearest school. For the overseas departments, the choice was made on an infra-communal scale with a regular subdivision of the area into a grid of $500 \mathrm{~m}$ on each side. For this scale, these maps therefore represent the distance from each location (500 $\mathrm{m}$ cell on each side) to the nearest school.

These initial results effectively provide a relevant and global overview of the relative differences in the distance between the population and schools. Nevertheless, this information must be qualified and we therefore remain cautious in the interpretation of the results.

Indeed, the principle of Euclidean distance, which is quick to implement and generally informative, does not allow in some cases to account for the distances "experienced" by the travelling population. This is particularly evident in certain territories that are difficult to access (mountainous areas, among others), where "distance" and "distance-time" have very different meanings. A desirable extension of this work in the future could therefore be the more refined calculation of a network distance (travel distance on traffic networks), from which time distances (travel times on networks) could be derived.

Similarly, this initial assessment of distances should be refined according to the overall traffic conditions in the territory where population travel is multifaceted: integrating public transport networks, the different modes of travel (car, motorcycle, pedestrians, etc.), the traffic and speeds used, which determine travel times, etc.

These maps therefore constitute a first exploration of a problem of access to educational places, with multiple dimensions that will then have to be analyzed globally.

Box 1.1 Comments on the methodology: Euclidean distance maps to schools (source: Mohand Medjkane and Thierry Saint-Gerand - UMR IDEES CNRS - Caen-Normandy University)

Along with the regional education authorities of French Guiana and Réunion Island, those of Reims, Dijon, Montpellier, Grenoble, Toulouse and Corsica are the only ones to have areas where pupils from municipalities that are not equipped are located more than $20 \mathrm{~km}$ as the crow flies from the training offer (see Figure 1.3). The diagonal of the empty space, oriented northeast/southwest, reappears logically here. 


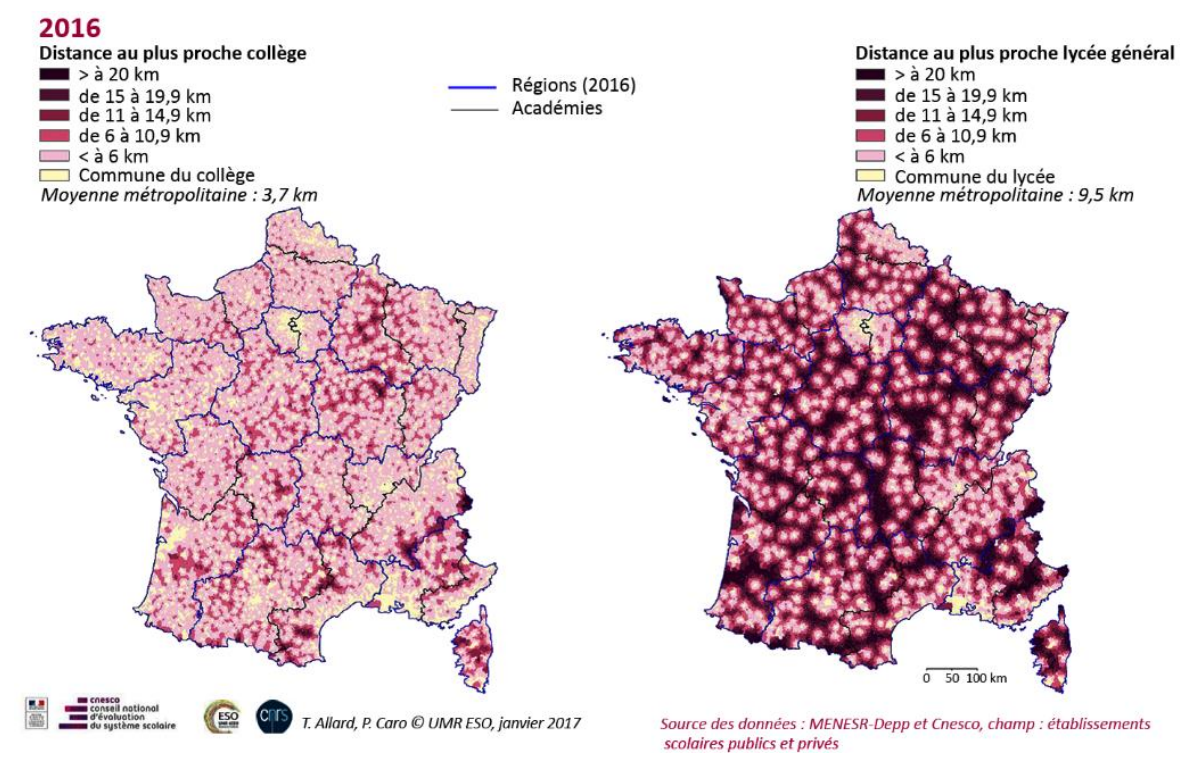

Figure 1.3. Euclidean distance to the nearest middle school and the nearest high school (LEGT), public or private, in metropolitan France, in 2016, for unequipped municipalities

The distances as the crow flies to the nearest general and technological high school show the same areas of low density as in the case for middle schools, but in these areas the number of municipalities concerned is higher. The number of regional education authorities concerned by this phenomenon is also higher. To the "rural" regional education authorities of Reims, Dijon, Montpellier, Grenoble, Toulouse and Corsica, all the others should be added, with the exception of the more "urban" ones of Strasbourg, Rouen, Créteil, Versailles, Paris and Martinique. The location of the equipped prefectures, central in their department, highlights many communes located on the departmental borders (from 16 to more than $20 \mathrm{~km}$ from the high school). This applies to the margins of the departments of Meuse and Marne, Haute-Marne and Haute-Saône, Puy-de-Dôme and Creuse, Ardèche and Lozère, etc.

It is more relevant to map inequalities of access to the same educational establishments, but taking into account road access times under normal traffic conditions (INSEE METRIC method). This approach highlights the same areas in metropolitan France that are disadvantaged in terms of road accessibility. The latter underestimates the transport times that some pupils, particularly schoolchildren, have to endure, as school transport follows non-linear collection routes. 


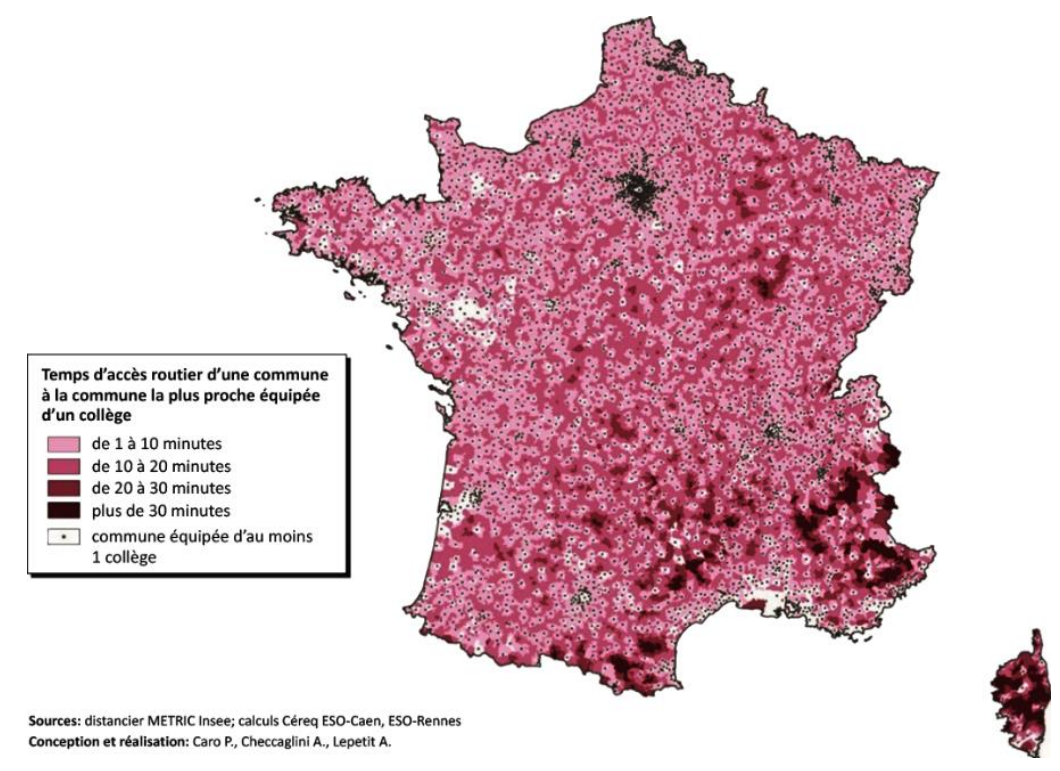

Figure 1.4. Road access time from an unequipped commune to the commune equipped with the nearest middle school in 2016

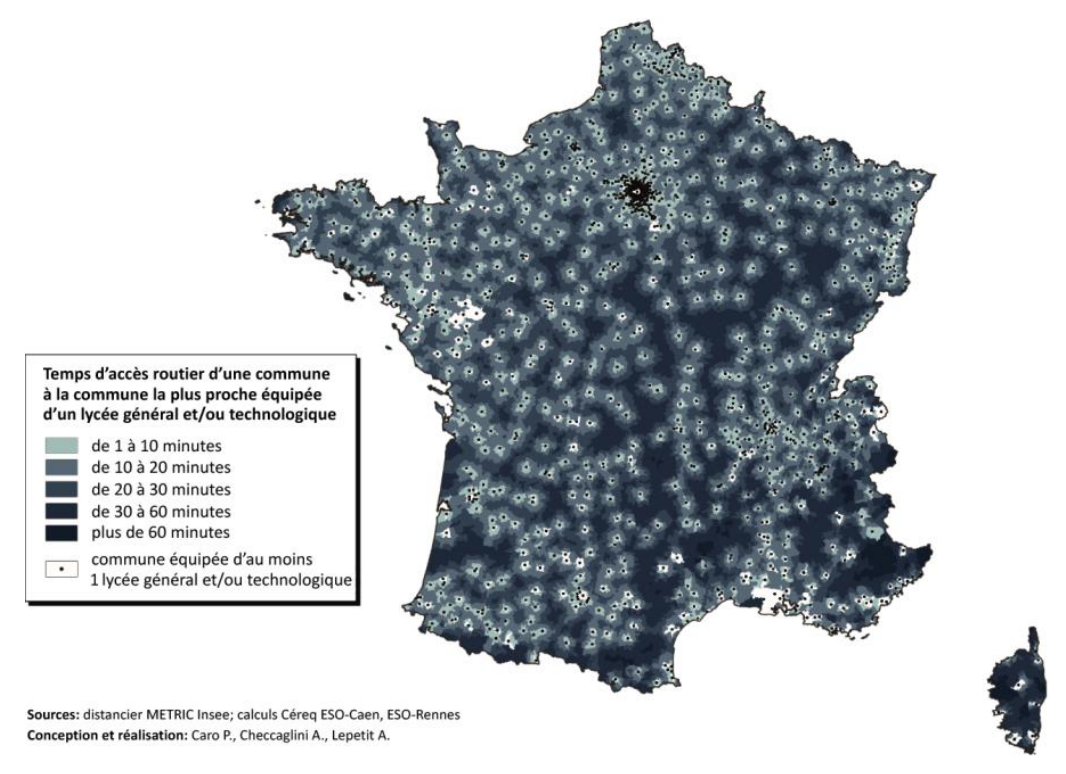

Figure 1.5. Road access time from an unequipped municipality to the municipality equipped with the nearest general and/or technological high school in 2016 

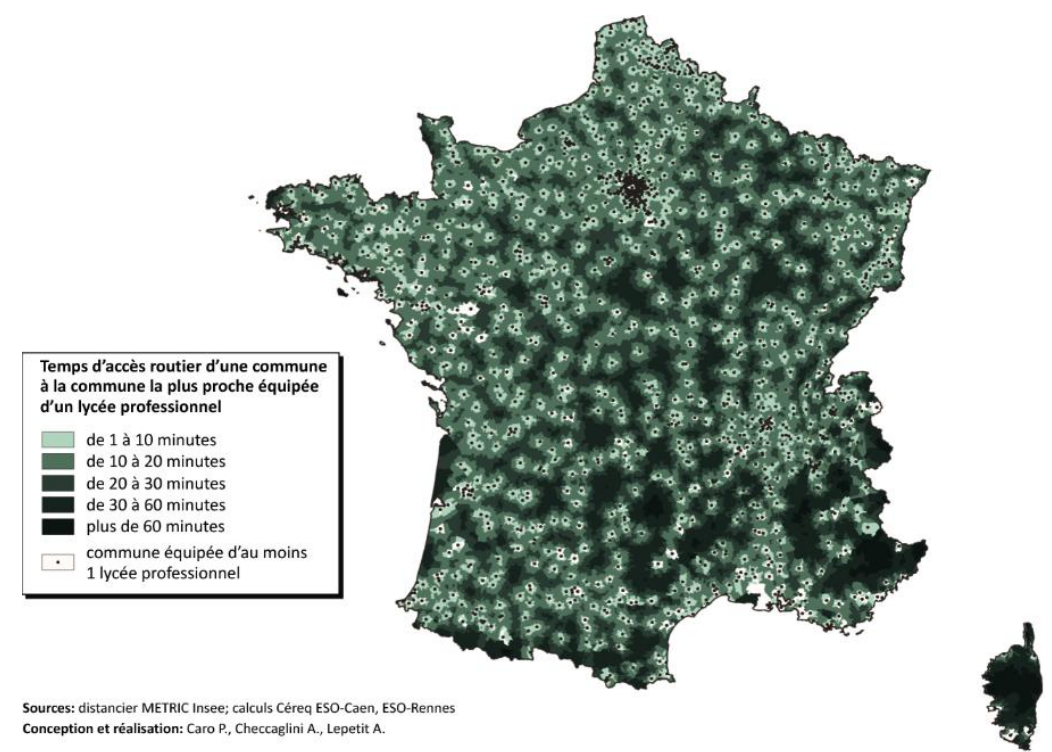

Figure 1.6. Road access time from an unequipped municipality to the municipality equipped with the nearest high school in 2016

The most disadvantaged areas in terms of access times to middle school are mainly rural mountain areas, often located at the margins of certain regions (see Figure 1.4). These areas also include municipalities classified by INSEE as having very low density. Road access times from a municipality that is not equipped to the nearest one equipped with a public or private middle school thus vary from a few minutes to more than 30 minutes in 2015, or even more than one hour, for some Corsican municipalities in particular.

The center and north of $\mathrm{PACA}^{8}$ (hinterland of the Alpes-Maritimes, Alpes-deHaute-Provence, Hautes-Alpes), as well as the whole south-east of Rhône-Alpes (Savoie, Isère, Drôme) are in the same situation. To the south-east of the Massif Central, access times are also among the longest in Ardèche, Lozère, Aveyron or Haute-Loire, at the margins of the Auvergne, Languedoc-Roussillon and Rhône-Alpes regions. The same applies near the Spanish border in the Pyrénées-Orientales, Aude and Ariège. Further north, access times are unfavorable, but to a lesser extent (20 to 30 minutes), along the entire diagonal of the empty space, i.e. from the Meuse and Ardennes to the Dordogne and Lot, via the Haute-Marne, the Côte-d'Or, the Allier, the Corrèze or the Cantal. Here again, regional borders coincide with difficulties of

8. Provence-Alpes-Côte d'Azur region. 
road access. The diagonal of the empty space coincides with the contact between Champagne-Ardenne and Burgundy, Burgundy and Auvergne, Auvergne and Limousin, Limousin and Aquitaine.

In total, the centre of gravity of this group of disadvantaged areas with regard to road access times is located in the south-eastern quarter of metropolitan France, somewhere between Languedoc-Roussillon (Occitania), PACA and AuvergneRhône-Alpes. The low population density and mountainous terrain in these areas generate a looser network of middle schools than elsewhere, resulting in longer access times. The regions of the Grand Est and Bourgogne-Franche-Comté are also affected by this phenomenon, but for a smaller number of municipalities.

These same areas in the same regions constitute the heart of rural France far from general and/or technological high schools and vocational high schools (see figures 1.5 and 1.6), but the access time between equipped and unequipped communes is increasing. The notion of a school divide thus makes sense because the same areas under low urban influence combine unfavorable accessibility for all types of schools. In addition to accessibility to schools, an equally important dimension for schooling lies in the human resources available in these schools.

\subsection{Teachers with different profiles depending on the municipalities and regional education authorities}

In 2015, young teachers (under 30 years of age) and unqualified staff were concentrated in the regional education authorities of Créteil, Versailles, Amiens and Guiana, where the majority of the risks of school failure and drop-out is partly located (Boudesseul et al. 2016).

The profile of teachers working in middle and high schools partly reflects the attractiveness of the regional education authorities in the south, west and capital (Veschambre 1994). Rennes, Bordeaux, Toulouse or Montpellier are attractive centers in the analysis of the inter-academic movement of high school teachers (Hilary and Louvet 2014). On the other hand, the Créteil, Versailles and Amiens trio is the cluster seen as having the most deterring features.

Like the migratory flows observed from census to census, many teachers want to access a brighter regional education authority where student success is above average and where a metropolis has developed, such as Rennes, Nantes, Bordeaux, Toulouse or Grenoble. It is striking to note that the Paris-Créteil regional education authorities held, in 2012 as in 1990, the record for the highest number of teachers over 50 years 
of age (24.6\% in Paris in 1990) and the lowest (11.1\% in Créteil in 1990 (MEN-DEPP 1993, p. 114)).

The local composition of the teaching staff can be understood via the proportion of young people under 30 years of age and that of those over 50 years of age at the level of all high schools in the same commune. Academically, there is a radical opposition between Paris and its peripheries (Versailles and Créteil). The proportion of teachers over 50 years of age varies by a factor of two between Paris and Créteil (see Figure 1.7).

In the first case, the regional education authority has the highest proportion of teachers over 50 years old due to an ageing teaching staff population with low turnover, while in the second case, it is a high turnover regional education authority with many vacancies. The youngest begin working more often than in Paris. The regional education authorities of French Guiana, Lille and Amiens share the same profile as the Parisian suburbs, for the same reasons. Some newly qualified staff assigned to French Guiana leave their posts, based on rivers, for example, which generates a high turnover (commune of Saint-Laurent du Maroni in north-western French Guiana in a border position).

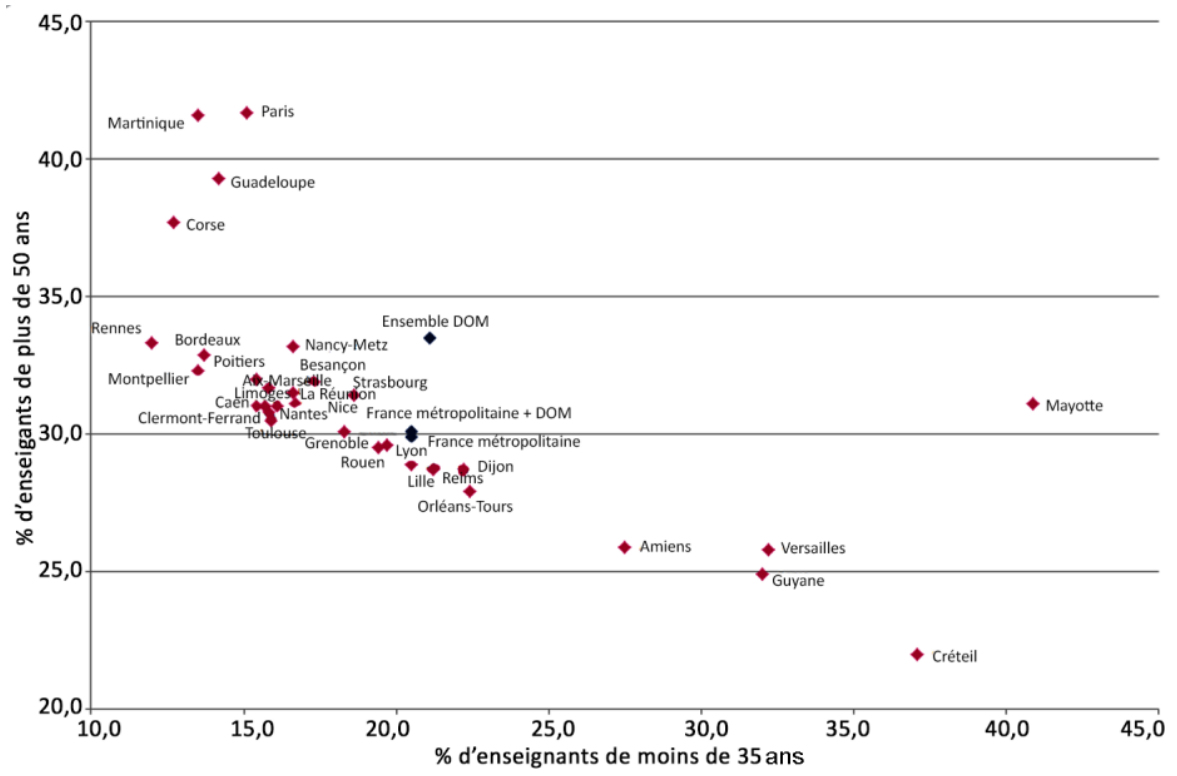

Figure 1.7. High school teachers: proportion of over-50s and under-35s, at the beginning of the 2015 academic year, according to the regional education authorities (source: MENESR DEPP, based on "Salary slips", December 2015) 
COMMENT ON FIGURE 1.7 - In 2015, the Créteil regional education authority had $37.1 \%$ of teachers under 35 years of age, the proportion of those over 50 years of age was $22 \%$. On the other hand, the Paris regional education authority had a $41.7 \%$ ratio of teachers over 50 years old, almost double that of Créteil.

For the regional education authorities of Montpellier, Guadeloupe, Martinique, Limoges and Corsica, the ratio increased considerably over the period. The age structure was therefore more unbalanced than it was with, for example, 12 times more teachers over 50 than teachers under 30 in Montpellier in 2014 compared to about 5 times more in 2005.

The other regional education authorities retain their profile, the relative youth of the teachers in Amiens, French Guiana, Versailles and Créteil contrast with the maturity of the latter in Paris, Bordeaux and Rennes. Among the factors that explain this age structure, spousal employment opportunities in the different regions and attachment to region of birth could play a role.

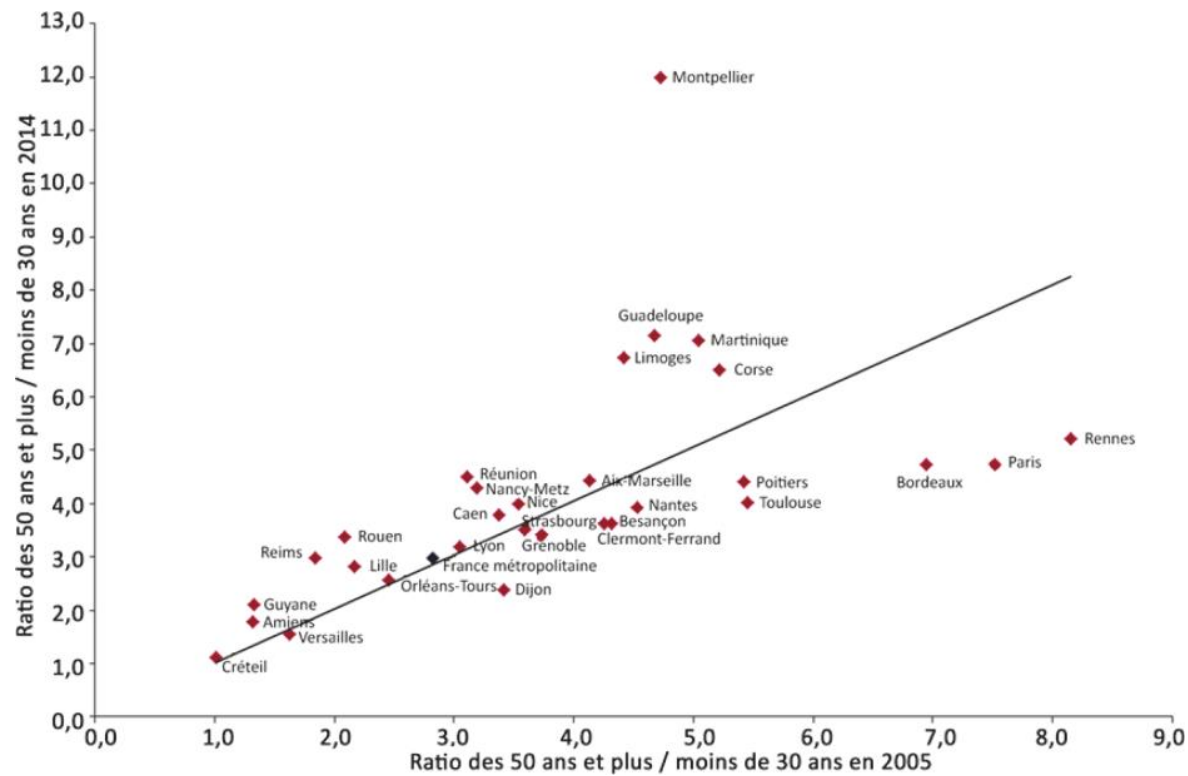

Figure 1.8. High school teachers: change in the ratio of over-50s to under-30s from 2005 to 2014 (sources: Geography of schools in 2011 and social balance sheet of the French Ministry of National Education, Higher Education and Research 2013-2014; data: MENJVA-MESR DEPP, 2010 pay file and MENESR-DEPP, 2014 pay file). 
COMMENT ON FIGURE 1.8 - In the Montpellier regional education authority, in 2005, the ratio was 4.7, so there were 4.7 times more teachers aged 50 and over than teachers aged under 30. In 2014, this ratio stoodat 12, the proportion of teachers aged 50 and over in the regional education authority was 12 times higher than that of those under 30 .

This first observation must be refined at the communal and cantonal level by summing up all middle and high school teachers, public or private, according to their age (see Figure 1.9). In middle school, the proportion of teachers under 30 years of age is highest in Dugny in Seine-Saint-Denis (56\% in 2014), which is part of the Créteil regional education authority, while it does not reach $1 \%$ in Vannes in the Rennes regional education authority. The municipality of Dugny has 10,200 inhabitants ${ }^{9}$, more than $38 \%$ of the inhabitants over 15 years of age are without a diploma and $48.5 \%$ of households are taxed on their income. Vannes $(53,032$ inhabitants) ${ }^{10}$ is much more socially privileged ( $27.1 \%$ of people have no diploma and $57.8 \%$ are taxed households). Does the youth of teachers systematically match up with social housing and the impoverishment of communes? This is true in the case of Parisian regional education authorities (Botton and Miletto 2018).

The average share of teachers under 30 years of age per canton in public middle schools was around $12 \%$ in 2014. This is the case, for example, in a canton such as Bollène (regional education authority of Aix-Marseille). The proportion of young teachers is highest in the 1st and $2^{\text {nd }}$ Parisian suburbs (more than $40 \%$ in Grigny or Evry), especially in the eastern and northern parts, the poorest in Île-de-France (more than $40 \%$ in Le Bourget, La Courneuve, Villepinte, Stains or Pierrefitte-sur-Seine). The margins of the Paris urban area are equally affected (radius of 70 to $80 \mathrm{~km}$ from Paris), towards Yonne (Dijon regional education authority), Eure (Rouen regional education authority), Loiret (Orléans-Tours regional education authority), or Marne (Reims regional education authority). The same is true in Mayotte and in the coal basin of the Lille regional education authority, which is still undergoing industrial conversion. The demographic growth and the mass of young people to be enrolled in school in these areas leads to many vacancies. On the other hand, all municipalities in large urban areas have situations close to the average, such as Fort-de-France, Reims, Nantes or Besançon. The attractive regional education authorities, with regard to the wishes for the assignment and transfer of teachers over the long term (1995-2015), concentrate municipalities where the proportion of young people is lower than the average or equivalent (Atlantic and Mediterranean coasts, regional education authorities of Rennes, Nantes, Bordeaux, Toulouse, Aix-Marseille, etc.). These last three regional

9. https://www.insee.fr/fr/statistiques/1405599?geo=COM-93030.

10. https://www.insee.fr/fr/statistiques/1895081. 
education authorities (Bordeaux, Toulouse, Aix-Marseille), as well as the one in Nice, already stood out in 1990-1991 with ratios of teachers over 50 years of age of more than $18 \%$ (MEN-DEPP 1993, p. 29).

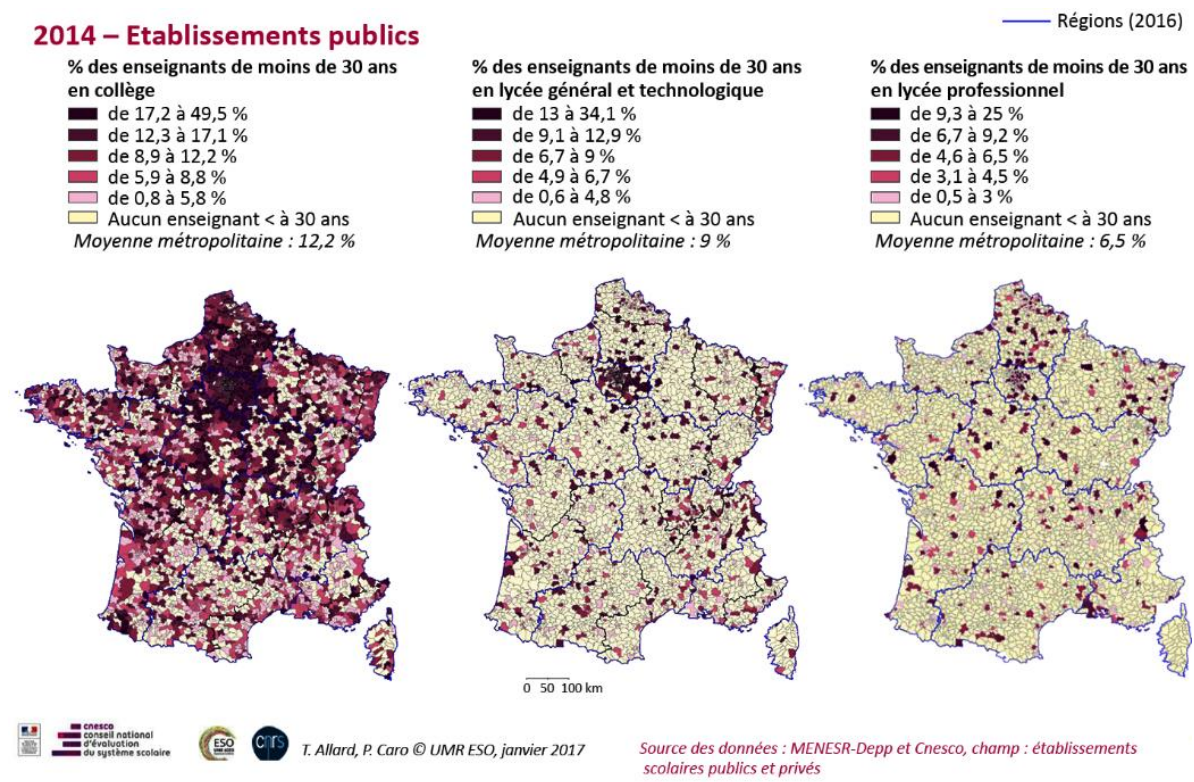

Figure 1.9. Percentage of middle school, general high school (LEGT) and public professional teachers under 30 years of age per equipped canton in 2014

The proportion of teachers working in public middle schools under 30 years of age is highest in the canton of Le Bourget $(49.5 \%)$ in the Seine-Saint-Denis department (Académie de Créteil). The proportion of teachers working in public general and technological high schools under 30 years of age is highest in the canton of MitryMory $(34.1 \%)$. The proportion of teachers working in public vocational high schools under 30 years of age reaches its maximum in the canton of Suresnes (25\%) in the department of Hauts-de-Seine (Versailles regional education authority), while less than $1 \%$ work in Bastia, La Rochelle or Aix-en-Provence.

The observation is identical to the examination of data relating to public general and technological high schools (LEGT), always at canton level. The record for young teachers is held by Mitry-Mory (34.1\%), with less than $2 \%$ in Biarritz, Dinard, Gap, Royan or Anglet, for example. Conversely, the ratio of teachers under 30 years of age for this category of schools is at its lowest in Gap (less than 1\%). This small tourist resort in the Southern Alps is at odds with Le Bourget in terms of social fabric $(29.9 \%$ 
of people aged 15 and over without a diploma in Gap compared with $42.4 \%$ in Le Bourget in 2013).

The range of differences narrows when focusing on the share of young teachers in public vocational high schools. The canton of Suresnes (Versailles regional education authority) is in an extreme situation with $25 \%$ of teachers under 30 years of age. In the heart of this canton, the municipality of Suresnes is home to a disadvantaged, impoverished and vulnerable population (risk of unemployment), since the proportion of inhabitants over 15 years of age without a diploma (20.5\% in 2013) ${ }^{11}$ and the household income tax rate at the same date $(75.9 \%)$ are well above the average. At national level, the opposition between Parisian peri-urban and urban areas in the "province" is confirmed. A major difference appears with this indicator, since many small and medium-sized urban areas (from 30,000 to 150,000 inhabitants in 2012, such as Alençon 68,000 inhabitants, or Colmar 130,000 inhabitants), with the exception of Brittany, are distinguished from the most populated, metropolitan or not, where the ratios are lower (Nantes, Reims, Bourges, Bourges, Besançon, Valence, etc.). Brittany has little turnover its teaching staff due to the stability of teachers in their positions. It is difficult to enter, which is one of the reasons why the ratios of young people are high at the gates of the Rennes regional education authority (Orne, Sarthe, etc.). We are as close as possible to the day when we will be able to access this regional education authority (sufficient number of points in the allocation mechanism) $)^{12}$.

With the regional education authorities of Versailles and Créteil, those of Lille, Amiens, Orléans-Tours, Nancy-Metz and Strasbourg are the youngest. They all have an economic and social profile marked during the $19^{\text {th }}$ and $20^{\text {th }}$ centuries by intense industrialization, a source of development of vocational education.

After the inequalities linked to teachers' ages, those linked to their status are analyzed at cantonal level (proportion of non-accredited teachers), but this time the

11. https://www.insee.fr/fr/statistiques/1405599?geo=COM-92073.

12. An inter-academic scale defined nationally and academic scales established by the rectors and the vice-rector allow the classification of requests as well as the elaboration of movement projects. However, they are only indicative. The scales first of all reflect the legal and regulatory priorities for processing the requests of certain staff: bringing together spouses, disabled officials and staff working in urban areas where particularly difficult social and security problems arise, school mapping measures, etc. They give priority to elements related to legal priorities and, to a lesser extent, take into account other elements related to: personal situation; career situation (length of service and post); the individual situation of the staff member. 
numbers are aggregated for middle, LEGT and vocational, public and private high schools (see Figure 1.10).

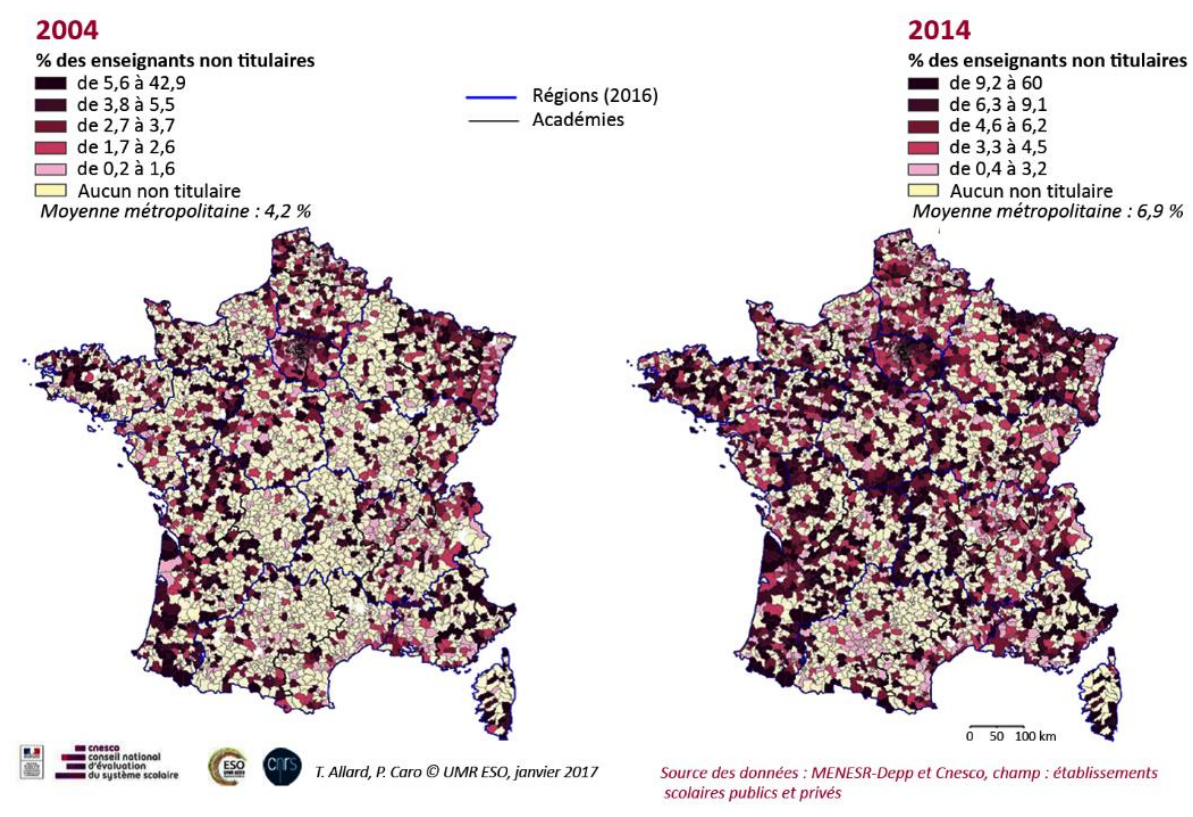

Figure 1.10. Ratio of teachers in public and private middle schools and high schools with unqualified staff among all teachers in 2004 and 2014 studied by canton

\begin{tabular}{|c|c|c|}
\cline { 2 - 3 } & $\mathbf{2 0 0 4}$ & $\mathbf{2 0 1 4}$ \\
\hline Guadeloupe & 8.2 & 10.7 \\
\hline French Guiana & 25.8 & 39.3 \\
\hline Réunion Island & 4.3 & 7 \\
\hline Mayotte & - & 26.8 \\
\hline $\begin{array}{c}\text { Total overseas } \\
\text { departments and } \\
\text { regions }\end{array}$ & 8.7 & 15.3 \\
\hline
\end{tabular}

Table 1.1: Ratio of unqualified staff in 2004 and 2014 (in \%) 
In 2014 , more than $86 \%$ of teachers working in the commune of Grand-Santi in French Guiana did not have a qualification. The entire overseas departments of France are in a somewhat comparable situation, except for Réunion Island (see Table 1.1). Saint-Laurent-du-Maroni has 225 teachers, more than three-quarters of whom do not have a qualification. In metropolitan France, the regional education authorities of Versailles and Créteil have the same problem as those overseas, namely a difficulty in attracting and retaining their teachers. Cantons such as Le Palais, Annot and Ile d'Yeu have a record number of unqualified teachers (50 to 60\%). To compensate for the lack of candidates to fill their posts, the education officers of these regional education authorities use individual temporary workers and other unqualified staff. In 1990, the proportion of unqualified staff among high school teachers in the Créteil education authority was already a record $13.6 \%$ compared with $12.4 \%$ in Versailles (then average $9.7 \%$ (MEN-DEPP 1993, p. 114)).

Between 2004 and 2014, the number of unqualified teachers, all types of establishments combined - middle schools, high schools, public and private increased slightly $(+3 \%$ on average), especially in Seine-Saint-Denis and Île-deFrance in general. It also increased in overseas France, from $8.7 \%$ to more than $15 \%$. In metropolitan France, as a general rule, growth is all the stronger as the cantons and communes are located at the margins of their departments, i.e. in the rural periphery under low urban influence. These areas, often poorly served by trains or highways and therefore poorly connected to large urban areas, are not places of work or residence sought by qualified teachers. Spousal employment is probably more difficult to find than in urban areas at the top of the urban hierarchy (Veltz 1996).

This is the case, for example, of the margins of Haute-Marne (border with Vosges), a department that itself constitutes a margin at the borders of the Paris basin and the regional urban system of the Grand Est, which are particularly affected by the growth in the rate of unqualified staff. The same applies to the borders between HauteGaronne and Ariège, as well as to the borders of Morbihan and Ille-et-Vilaine, or between south-east French Guiana and Brazil. These peripheries, which are poorly urbanized and therefore poorly equipped (private services, transport infrastructure), do not host a varied and diversified labor market, all of which works against the establishment of working households with higher education qualifications, as is the case for teachers. On the other hand, a decline in the rate of unqualified staff benefits areas well connected to transport networks such as the southern part of the department of Manche. This explanatory hypothesis does not exhaust the subject. 


\subsection{Conclusion}

How much of France is included when we analyze inequalities in the distribution of financial and human resources and inequalities in access to schools? After examining the inequalities in terms of financial allocation by local authorities to middle and high schools, the inequalities in road access to these establishments, and the disparities in the location of human resources in these establishments such as teachers, the use of the notion of the school divide does not seem excessive given the differences observed between cantons, departments and regional education authorities.

If we were to retain only one dimension of these divisions, it would undoubtedly be the one relating to the rate of unqualified teachers. The share of this type of teacher increased, as we have seen, on average in metropolitan France between 2004 and 2014 , from $4.2 \%$ to $6.9 \%$, but it multiplied by 1.7 in the overseas departments and regions over the same period, and went from $25.8 \%$ to $39.3 \%$ in French Guiana. The average metropolitan rate in this area is 2.2 times lower than that of the overseas departments and regions.

By broadening the scope, a school divide isolates the French overseas communities from metropolitan France, and within these overseas communities, French Guiana and Mayotte are clearly different from the other French overseas departments and territories. In metropolitan France, the regional education authorities of Amiens, Créteil and Versailles are opposed by their characteristics to those of Paris, Rennes, Montpellier or Bordeaux (age of teachers for example). On a finer scale, in metropolitan France, a divide separates mountainous rural areas from those on the crossing of the empty space, to the urban network and its peri-urban fringes, when we focus on inequalities in road access to educational establishments.

But this multiscalar observation needs to be confirmed by taking into account statistical data of the same nature over a decade to measure the possible stability of these divisions, a reduction in them or an aggravation. In addition, indicators such as those on road accessibility to schools would benefit from being refined by type of high school, for example (e.g. by providing industrial or tertiary training or by providing rare training).

\subsection{Bibliographical references}

Botton, H., Miletto, V. (2018). Quartiers, égalité, scolarité. Cnesco, Paris.

Boudesseul, G., Caro, P., Grelet, Y., Minassian, L., Monso, O., Vivent, C. (2016). Atlas des risques sociaux d'échec scolaire: l'exemple du décrochage, France métropolitaine et DOM. Céreq, Marseille. 
Brunet, R., Ferras, R., Thery, H. (1992). Les Mots de la géographie, dictionnaire critique. La Documentation française, Paris.

Caro, P. (2018). Inégalités scolaires d'origine territoriale en France métropolitaine et d'Outre-mer. Cnesco, Paris.

Caro, P., Rouault, R. (2010). Atlas des fractures scolaires. Une France à plusieurs vitesses. Autrement, Paris.

Champollion, P. (2018). Inégalités d'orientation et territorialité : l'exemple de l'école rurale montagnarde [Online]. Report, Cnesco. Available at: http://www. cnesco.fr/wp-content/uploads/2018/10/181026_Cnesco_Champollion_ecole rurale montagnarde.pdf.

DGCL (2015). Les budgets primitifs des régions. INSEE.

DGCL - DESL (2015). Budgets primitifs 2014 et 2015. INSEE.

Hilary, S., Louvet, A. (2014). Enseignants de collège et lycée publics en 2013 : panorama d'un métier exercé par 380000 personnes. Rapport Vue d'ensemble, portrait de la population, INSEE, 1-38.

Le Bras, H. (2013). Atlas des inégalités. Les Français face à la crise. Autrement, Paris.

MEN-DEPP (1993). Géographie de l'école, 1.

MEN-DEPP (2011). Géographie de l'école, 10.

MEN-DEPP (2013-2014). Bilan social du ministère de l'Éducation nationale, de l'Enseignement supérieur et de la Recherche.

MEN-DEPP (2014). Géographie de l'école, 11.

MEN-DEPP (2017). Géographie de l'école, 12.

Ripoll, F., Veschambre, V. (2005). Sur la dimension spatiale des inégalités : contribution aux débats sur la «mobilité » et le «capital spatial». In Rural-Urbain. Nouveaux liens, nouvelles frontières, Arlaud, S., Jean, Y., Royou, D. (eds.). PUR, Rennes.

Schneider, A., Botton, H., Miletto, V., Caro, P. (2018). État des lieux des inégalités scolaires d'origine territoriale en France [Online]. Summary document, Cnesco. Available at: http://www.cnesco.fr/wp-content/uploads/2018/10/181027_ Cnesco_synthese_rapport_national_Caro.pdf.

Simon, P., Delsol, B. (2015). Les budgets primitifs des départements. DGCL.

Veltz, P. (1996). Mondialisation, villes et territoires. L'économie d'archipel. PUF, Paris. 
Veschambre, V. (1994). Les professeurs du secondaire public : essai de géographie d'un groupe social. PhD thesis, Université de Caen. 